\title{
Symposium Introduction
}

\section{Introduction to the Symposium on 'Financial Risks and Economic Stability in Emerging Market Economies'}

\section{LUCJAN T ORLOWSKI}

Economics and finance, Sacred Heart University, 5151 Park Avenue, Fairfield, Connecticut 06825, United States. E-mail: orlowskiL@sacredheart.edu

Developing resilience to contagion effects from global financial crises and economic recessions has been an ongoing crucial task for policymakers in emerging market economies. The recent global financial crisis of 2007-2009 has underscored the importance of pursuing disciplined macroeconomic policies and of devising sound macroprudential regulations that would strengthen the immunity of emerging markets and their institutions to various types of risks, including credit, default, sovereign, liquidity and market risks. The studies included in this symposium are not intended to provide a comprehensive overview of financial vulnerabilities in a broad spectrum of emerging markets. Rather, they share a common aim of examining susceptibility of selected markets and institutions to various types of financial risk. In addition, they examine the transmission of risks from mature to emerging markets, as well as sovereign risk problems in emerging market economies and the contagion effects of financial crises. The papers analyze timely issues that have not been researched exhaustively in the literature, and thus remain subject to ongoing scholarly projects and debates, most of which stem directly from the economic quandaries that have arisen out of the recent global crisis.

All the papers included in this symposium were originally presented at the conference of the Society for the Study of Emerging Markets (SSEM) in Milas, Turkey in July 2010. They have been chosen from the pool of papers originally submitted for publication in Comparative Economic Studies through 
an initial screening by the conference organizing committee, and they were subsequently refereed by at least two anonymous reviewers.

The symposium opens with a paper by Hubert Gabrisch and Lucjan Orlowski, who investigate extreme financial market risks in the eurocandidate countries of Central and Eastern Europe. These risks are proxied by volatility outbursts of stock market indexes, inter-bank lending rates and exchange rates, all related to market turbulence engendered by the recent financial crisis. Such extreme risks in financial markets are detrimental to bank lending, business investment and consumption, thus they may ultimately inflict serious damage on long-term economic growth. The authors demonstrate that the scale of extreme market risks has been particularly large in the countries with weaker macroeconomic fundamentals and lax macroprudential regulations.

The second paper, by Değer Eryar, investigates the impact of the currency and maturity mismatch in the private sector in Turkey on the exchange rate risk that is captured by exchange rate volatility. Like the factors contributing to the 1997-1998 Asian financial crisis, the rising debt of the non-financial sector exacerbated exchange rate volatility in Turkey in the post-2001 crisis period. Eryar shows that the Central Bank of Turkey made several attempts to mitigate exchange rate volatility by providing the private sector with short-term liquidity injections. In conclusion, he advocates accumulation of sufficient liquid reserves by the central bank that could be used for reducing real exchange rate risk.

The following paper by Panayotis Kapopoulos and Sophia Lazaretou, analyzes the risks associated with the loans made by Greek banks in SouthEastern Europe (SEE). They employ a value-at-risk model to show that a high lending concentration by Greek banks in SEE has contributed to systematic risk, because system-wide variables cannot be diversified away. They compare systematic risk factors with the event probability of sovereign, country-specific risk, that is, unsystematic risk. The major finding of their study is that the unsystematic part of Greek banks' lending in the region has played a more critical role than the systematic one. They argue that the high country-specific risk in SEE has been exacerbated by the high debt-to-income levels and by the fiscal position indicators, such as the budget deficit-to-GDP and public debt-to-GDP ratios of these countries.

The final paper, by Adam Geršl and Petr Jakubik, underscores the importance of credit risk of commercial borrowers for bank lending in the emerging European economies. They demonstrate that the majority of nonfinancial borrowers in the Czech Republic use services of a single commercial bank lender who has in-depth knowledge of the borrowers' creditworthiness. They also find that this model of lending, based on a close relationship 
between predominantly regional banks and commercial borrowers, proved to be quite resilient during the recent financial crisis. It allowed the financial system to cushion the contagion from the global crisis that is normally strong when universal banks dominate domestic lending.

I wish to express my gratitude to the SSEM conference organizers, particularly to Professors Ali M. Kutan and Josef C. Brada, for assembling a large selection of quality papers addressing recent economic challenges faced by the emerging markets. The conference material has ultimately enabled us to bring together the studies included in this symposium. My special thanks go to the authors for their relevant contributions and expeditious revisions, and to the anonymous referees for their insightful reviews and useful comments. Without their collegial collaboration, this symposium issue would not be possible. 